$\mathrm{A} \mathrm{J}_{\mathrm{sins}} \mathrm{H}$

Received : 07.11.2014

Revised : 27.03.2015

Accepted : 13.04.2015

Members of the Research Forum

Associated Authors:

'Department of Horticulture, Dr.

Y.S.R. Horticultural University,

Venkatramanna gudem, WEST

GODAVARI (A.P.) INDIA

Email : dsa@drysrhu.edu.in

${ }^{2}$ Department of Horticulture, Dr. Y.S.R. Horticultural University, Rajendranagar, HYDERABAD

(TELANGANA) INDIA

Email : ranjani-21@gmail.com

${ }^{3}$ Department of Crop Physiology, College of Agriculture, Prof.

Jayshankar Telangana State

Agricultural University,

Rajendranagar, HYDERABAD

(TELANGANA) INDIA

Email : pvraophy@gmal.com

Author for correspondence :

L. SUHASINI

Department of Horticulture, College

of Horticulture, Dr. Y.S.R.

Horticultural University,

Rajendranagar, HYDERABAD

(TELANGANA) INDIA

Email : chinni18113@gmail.com
THEASIAN JOURNAL OF HORTICULTURE

Volume 10 | Issue 1 | June, 2015 | 53-59

Visit us -www.researchjournal.co.in

\title{
Physico-chemical properties of osmotically dehydrated karonda (Carissa carandas L.)
}

\section{SUHASINI, K. VANAJALATHA ${ }^{1}$, A.S. PADMAVATHAMMA ${ }^{2}$ AND P. VEKATESHWAR RAO ${ }^{3}$}

ABSTRACT : The present investigation was carried out during 2013-2014 at College of Horticulture, Rajendranagar, Hyderabad. The osmotic dehydration of karonda was studied with two concentrations of $\mathrm{NaCl} v i z ., 2$ per cent and 5 per cent, $\mathrm{NaCl}$ with three different durations of dipping times viz., 1, 2 and 3 hours. After osmosis of the karonda slices in the $\mathrm{NaCl}$ (salt) solutions, these were laid on the hot air oven for dehydration. After osmotic dehydration, the products were packed in high density polyethylene bags and stored in ambient temperature for a period of 4 months. The physico-chemical properties like moisture content, ascorbic acid, Fe content, acidity of the product were evaluated during the storage period. During storage, slight decrease in ascorbic acid, iron content, acidity and increase in moisture content of osmodried product of karonda was noticed. All the products were acceptable at all the storage periods. However, osmotic pre-treatment with 5 per cent $\mathrm{NaCl}$ for 3 hours was found highly acceptable.

KEY WORDS : Ascorbic acid, Karonda, Osmotically dehydrated, Physico-chemical properties, Salt

HOW TO CITE THIS ARTICLE : Suhasini, L., Vanajalatha, K., Padmavathamma, A.S. and Rao, P. Vekateshwar (2015). Physico-chemical properties of osmotically dehydrated karonda (Carissa carandas L.). Asian J. Hort., 10(1) : 53-59. 